Submitted on August 18, 2020.

\title{
Exogenic sources of vitamin-like substances and prospects for using yest in production of food products of special composition
}

\author{
(C) Galina V. Omelchenko \\ Rostov state medical University of the Ministry of health of Russia. Nakhichevan lane, 29. \\ Rostov-on-don, 344022.E-mail: o-g-v40@mail.ru
}

Keywords: vitamin-like substances, exogenous sources, synthesis, biochemical processes, role, human organism.

\section{Content}

1. Characteristics of vitamin-like substances, their benefits, sources

2. Relevance of studying Saccharomyces cerevisiae as a source of vitamin-like substances

3. Using yeast cultures as sources of vitamin-like substances

\begin{abstract}
The first half of the 20th century is characterized by discoveries in the field of biochemistry. During this period, the active substances necessary for the development of the body and maintaining homeostasis were first studied. After a long study of vitamins, scientists discovered a number of substances that have properties similar to vitamins, later they were called "vitamin-like substances". The mechanisms of regulation of the body's vital activity are always based on the course of special biochemical reactions, including with the participation of vitamin-like substances, which, unlike vitamins, can be synthesized by the body itself endogenously and come from exogenous sources (inside with food or in laboratory/industrial conditions). There is a need to maintain their balance through food intake. The article examines the role of vitamin-like substances of plant origin in the processes of vital activity of the organism, ensuring the implementation of specific tasks in the system of organs, cells and tissues. Due to the low quality of modern products, the concentration of useful components in their composition is reduced. Therefore, many people currently do not receive additional vitamin-like compounds and vitamin supplements are necessary to replenish them. The latter, due to the intense rhythm of life, people may forget to use or take irregularly. Therefore, the urgency of enriching the composition of familiar food products, in particular by means of yeast cultures, which are able to accumulate useful components in themselves, depending on the substrates consumed, has increased.

The aim of this work is to study the possibilities of using yeast cultures to enrich the composition of familiar food products with vitamin-like substances from plant sources.

Materials and methods. The article analyzes the possibilities of enriching familiar non-alcoholic food products by cultivating yeast cultures on substrates of plant origin. The role of vitamin-like substances in the biochemical processes of the body in comparison with the biologically active fermentative of yeast has been determined. To perform a systemic in-depth analysis, a synergistic principle was used to study the effect of the vitomin-like substances used on biochemical processes, that is, an analysis was carried out by studying the self-organization of the functional systems of the body without taking into account data on specialized pharmaceutical therapy. The research was carried out on the basis of the relevant Russian and English language information sources.

Results. To achieve this goal, the reasons for the need and indispensability of vitamin-like substances in the biological processes of the body were initially considered, their classification and dosage were briefly characterized. Further, the methods of enriching food products by means of yeast cultures are studied in detail and the influence of each compound or group found in information sources on the biochemical processes in the body is considered. The possibilities of using yeast as a source of vitamin-like substances and for carrying out the fermentation of plant objects for enriching food products and non-alcoholic beverages with special components are considered separately. The composition and benefits of the active fermentative of yeast have been investigated, it has been established that the composition of the vitamin-like substances of the final product has not been sufficiently studied. It was revealed that successful attempts are being made to use Saccharomyces cerevisiae for the formation of food products enriched with bioflavonoids with antioxidant properties.
\end{abstract}




\section{References}

[1] O.V. Yozefovich, A.A. Ruleva, S.M. Kharit, N.N. Murav'yova. Choosing vitamins. Current Pediatrics. 2010. No.1. P.172-176. (russian)

[2] I.P. Prokopenko, V.M. Volostnaya, M.V. Larsky. Sport food additive classification. Pharmacy \& Pharmacology. 2015. No.2(9). P.72-78. (russian)

[3] Yu.A. Lysikov, P.V. Druzhinin, A.F. Novikov. Vitamins and health. Electronic resource. URL: http://polonsil.ru/blog/43053232308/Sintezvitaminov-v-organizme-chelovek. date of access (16.09.2020).

[4] A.V. Arkhipov. Vitamin-like substances and their functions in the metabolism in the body of animals. Materials of the International Scientific and Practical Conference "Intensity and Competitiveness of Livestock Branches". 2016. P.6-13. (russian)

[5] Register of medicines. Biophysical, biochemical and energy mechanisms of regulating the functions of cells in the body. Electronic resource. URL: https://www.rlsnet.ru/books_book_id_2_page_23.htm. date of access (09.03.2020).

[6] Great medical encyclopedia ed. Petrovskogo B.V. Electronic resource. URL: https://xn--90aw5c.xn-c1avg/index.php/\%D0\%97\%D0\%B0\%D0\%B3\%D0\%BB\%D0\%B0\%D0\%B2\%D0\%BD\%D0\%B0\%D1 $\% 8 \mathrm{~F} \% \mathrm{D} 1 \% 81 \% \mathrm{D} 1 \% 82 \% \mathrm{D} 1 \% 80 \% \mathrm{D} 0 \% \mathrm{~B} 0 \% \mathrm{D} 0 \% \mathrm{BD} \% \mathrm{D} 0 \% \mathrm{~B} 8 \% \mathrm{D} 1 \% 86 \% \mathrm{D} 0 \% \mathrm{~B} 0$ - date of access (09.03.2020).

[7] N.V. Topchiy, A.S. Toporkov. Methylmethionine Sulfonium chloride in complex medical and preventive programs. Medical Council. 2019. No.3. P.60-68. (russian)

[8] Zh. Kostantin, V.V. Kugach. Vitamins and their role in the body. Pharmacy Bulletin. 2006. No.2(32). P.58-70. (russian)

[9] A.K. Gevorkyan. Deficiency of vitamins and microelements: opinion of a practicing pediatrician. Pediatric Pharmacology. 2011. No.6. P.125-126. (russian)

[10] T.M. Motovilova. Modern approach to the prevention and correction of vitamin and mineral deficiency in pregnant and lactating women. RMJ. Mother and child. 2014. No.1. P.66-70. (russian)

[11] P.I. Shilov, T.K. Yakovlev. Vitamins in the practice of a military doctor. Moscow: Publishing house of the Military medical order of Lenin of the Kirov Academy. 2016. 216p. (russian)

[12] V.B. Prozorovsky. Vitamins for all ages. Complete reference guide. Everything you need to know about vitamins and microelements. Moscow: tsentrpoligraf. 2015. 160p. (russian)

[13] O.A. Gromova. Formulation of vitamin complexes, supplying physiological needs in vitamins in children. Current Pediatrics. 2009. No.6. P.77-84. (russian)

[14] N.P. Oboturova, N.V. Sudakova, V.S. Kokoeva, A.S. Zaitsev. The use of plant extracts in the production of food products. Food industry. 2013. No.6. P.48-50. (russian)

[15] K.A. Kosacheva. Model of the physiological system biosynthesis of vitamins and vitamins-like substances in the body of a healthy person. International student scientific bulletin. 2017. No.3. P.78. (russian)

[16] N.Yu. Germanovich, N.V. Rumyantseva, I.V. Kotovich, V.P. Baran. Biochemistry of vitamins (study guide). Vitebsk: VGAVM. 2004. 36p. (russian)

[17] M.A. Ogay, E.V. Kovtun, A.A. Chakhirova, A.B. Samoryadova, Z.N. Bogatyreva. Development and research of phytoextracts containing flavonoids. Scientific results of biomedical research. 2018. No.2. P. 90-103. (russian)

[18] V.A. Tutelyan, A.A. Makhova, A.V. Pogozheva, E.V. Shikh, E.V. Elizarova, S.A. Khotimchenko. Lipoic acid: physiological role and prospects for clinical use. Nutrition issues. 2019. No.4. P.6-11. (russian)

[19] T.V. Mohort. Alpha lipoic acid: multifactorial effect and substantiation of the possibilities of use in diabetes mellitus. Medical News. 2011. No.3. P.67-71. (russian)

[20] G.N. Shivrin. Nutrition and Digestion/Popular Science Edition. Ryazan: NP "Voice of the province". 2014. 238p. (russian)

[21] E.V. Pastushkova, N.V. Zavorokhina, A.V. Vyatkin. Vegetable raw materials as a source of functional food ingredients. Bulletin of the South Ural State University. Series: Food and Biotechnology. 2016. No.4. P.105-113. (russian)

[22] A.M. Nosov. The use of cellular technologies for the industrial production of biologically active substances of plant origin. Biotechnology. 2010. No.5. P.8-28. (russian)

[23] N.S. Ruchay, I.A. Grebenchikova. Microbial synthesis technologies. Electronic course of lectures for students of specialty 1-48 0201 "Biotechnology". Minsk: BSTU. 2014. 167p.

[24] L.L. Danilina. Biologically active substance (options) and biologically active food additive (options). Patent. No. RU 2005105958 A. 2005. 
[25] Perli T., Wronska A.K., Ortiz-Merino R.A., Pronk, J.T. Daran J.M.. Vitamin requirements and biosynthesis in Saccharomyces cerevisiae. Yeast. 2020. Vol.37(4). P.283-304. doi:10.1002/yea.3461

[26] Ya.F. Zverev. Flavonoids through the eyes of a pharmacologist. Features and problems of pharmacokinetics. Reviews on clinics. pharmacol. and lek. therapy. 2017. No.2. P.4-11. (russian)

[27] O.I. Ponomareva, V.G. Chernysh, E.V. Borisova, I.P. Prokhorchik. Influence of cultivation conditions on the yield and quality of baker's yeast. Scientific journal NRU ITMO. Series "Processes and Apparatus for Food Production". 2011. No.2. P.1-10. (russian)

[28] E.M. Serba, K.V. Rachkov, E.V. Orlova, L.V. Rimareva, N.S. Pogorzhelskaya, V.A. Polyakov. Fractional composition and functional properties of yeast biomass fermentolysates. Bulletin of the Samara Scientific Center of the Russian Academy of Sciences. 2013. No.3-5. P.1680-1681. (russian)

[29] L.L. Danilina. Biologically active substance (options) and biologically active food additive (options). Patent. No. RU 2297161 C. 2007.

[30] I.G. Belyavskaya. Antioxidant properties of wheat flour bakery products using non-traditional types of raw materials. Storage and processing of agricultural raw materials. 2018. No.3. P.8-19. (russian)

[31] I.V. Kalinina, R.I. Fatkullin, D. Ivanova, Y. Kiselova-Kaneva, M. Todorova. Study of the influence of food ingredients based on dihydroquercetin on the rheological properties of dough for bakery products. Bulletin of the South Ural State University. Series: Food and Biotechnology. 2019. No.1. P.21-29. (russian)

[32] T.M. Tananaiko, A.A. Yurchenko. New functional non-alcoholic fermentation drinks. Age of Science. 2019. No.20. P.198-207. (russian) 